\title{
特集 外科系各科におけるがん免疫療法
}

\author{
特集にあたって \\ 近畿大学医学部外科 ${ }^{1)}$, 東京女子医科大学東医療センター外科 ${ }^{2)}$ \\ 奥野 清隆 ${ }^{1)}$ 小川 健治 ${ }^{2)}$
}

\section{はじめに}

1991年Boonによってヒトがん拒絶抗原が報告 されて以来, 多くのがん腫においてがん拒絶抗原 が報告され，ペプチドワクチンを用いた臨床研究 も盛んに行われてきた，正に本来のがん特異的な 免疫療法の到来であり，ここ10年は飛躍的に進歩 し, 2010年には米国FDAによって進行前立腺がん に対する治療用ワクチン (Provenge ${ }^{\circledR}$ ) が承認さ れた. 2011年, 本学術集会において標記のシンポ ジウムが企画され, 外科系各領域での最新の免疫 療法が提示された (表). 特集にあたり, 司会者の 立場から, 本シンポジウムを俯瞰してみたい.

\section{1.ペプチドワクチン}

進行・再発性の食道癌 (三村, 山梨大), 大腸癌 (硲, 山口大 ; 奥野, 近畿大), 膵癌 (宮澤, 和歌 山医大）に対してHLA-A24のクラス I 拘束性ペプ チドを用いてキラーT細胞（CTL）を誘導した試 みが報告された。これらはがん腫高発現性の, あ るいは腫瘍新生血管を標的としたペプチドで, 数 種類のカクテルを抗がん剤とともに用いる研究デ ザインが多い. いずれも東大, 医科研, 中村祐輔 教授を中心とした全国ネットワークの共同研究で あり，CTL assayは東大医科研ですべて行ってい る.このことは, お互いのデータの互換性, 信頼 性に繋がる大きな利点である。食道癌, 膵癌は悪 性度が高く，標準療法のレジメンがそしいことも あって，すでに第 II 相，第吕相試験が実施され， 近いうちに企業主導治験に引き継がれるレベルに

第36回日本外科系連合学会学術集会シンポジウム 2 連絡先 奥野清隆

₹589-8511 大阪府大阪狭山市大野東377-2

近畿大学医学部外科
達している.


各種進行癌に対する臨床試験を展開してきたのは 札幌医大の外科学, 病理学のグループで, 今回は 進行膵癌に対する成績が報告された（龟嶋, 札幌 医大).

また，新たに胃癌における増殖シグナルに関与 する遺伝子（ERas）由来の新規ペプチドワクチン を開発し，これから臨床試験を行う予定との研究 も紹介された（田中，大阪市大）。

\section{2. モノクローナル抗体}

細胞増殖に関連する因子やそのレセプターに対 するモノクローナル抗体 (抗HER2抗体や抗EGFR 抗体）は分子標的治療薬と総称され, 今では乳癌, 大腸癌治療における重要な位置を占めている. 三 村らは食道扁平上皮癌において HER2発現を検討 したうえで培養癌細胞を用いてそれら抗体の増殖 抑制作用, ADCC活性, apoptosis誘導能などを検 討し, 食道癌における将来の臨床応用の可能性に ついて言及した (三村, 山梨大).

\section{3. 自家腫瘍ワクチン}

丸山らは神経膠芽腫に対して切除ホルマリン標 本から自家腫瘍ワクチンを作製し, 腫瘍特異的 CTLを誘導する試み（第 I / II 相試験）を報告し た (丸山, 東京女子医大). 本法は前出のペプチド ワクチンのような患者HLA抗原, 担がん腫瘍抗原 との適合性を考慮することなく臨床応用できるの が最大の利点である．ホルマリン固定，パラフィ ン固定サンプルからも作製できるとのことで，将 来的には他の腫瘍系への応用が期待できる. 
表 シンポジウム 2 外科系各科におけるがん免疫療法

\begin{tabular}{|c|c|c|c|}
\hline 番号 & 演者 & 所属 & 演題名 \\
\hline 1 & 三村耕作，他 & 山梨大, 第一外科 & 食道癌に対する免疫療法の新規開発一HER family分子標的治療とペプチドワクチン一 \\
\hline 2 & 田中浩明，他 & 大阪市立大院, 腫瘍外科 & 胃癌に発現するERasをターゲットとしたHLA-A*2402拘束性エピトープペプチドの同定 \\
\hline 3 & 砝 彰一, 他 & 山口大院, 消化器·腫瘍外科 & 新規エピトープペプチドワクチンを用いた新しい大腸癌免疫療法の開発 \\
\hline 4 & 奥野清隆, 他 & 近畿大, 外科 & 標準療法抵抗性の進行·再発大腸癌に対するペプチドワクチン+UFT/LV療法 \\
\hline 5 & 小寺由人, 他 & 東京女子医大, 消化器外科 & 原発性肝癌に対する樹状細胞ワクチン療法 \\
\hline 6 & 亀嶋秀和, 他 & 札幌医大，第一外科 & 進行·再発膵癌に対するサバイビン2Bペプチドによるワクチン療法 \\
\hline 7 & 宮澤基樹，他 & 和歌山医大, 第 2 外科 & 進行膵癌に対する腫瘍新生血管を標的としたペプチドワクチン療法 \\
\hline 8 & 丸山隆志, 他 & 東京女子医大, 脳神経外科 & 初発神経膠芽腫に対する自家腫瘍ワクチンを用いた免疫療法 \\
\hline 9 & 島川 武, 他 & 東京女子医大東医療セ, 外科 & 活性化自己リンパ球移入療法有効例の検討 \\
\hline 10 & 小林博人，他 & 東京女子医大, 泌尿器科 & 泌尿器科悪性腫瘍に対する自己活性化 $\gamma \delta$ 型T細胞を用いた免疫療法 \\
\hline 11 & 佃 守 & 横浜市立大, 耳鼻科・頭頸部外科 & $\begin{array}{l}\text { 頭頸部癌の免疫療法の現状と将来 } \\
\end{array}$ \\
\hline
\end{tabular}

\section{4. 活性化リンパ球移入}

島川ら（東京女子医大）は種々の固形癌に活性 化自己リンパ球移入療法を施行した650例の結果 を報告した，腫瘍縮小例は少なく，臨床効果は満 足できるものではないが, QOLの改善や病勢制御 (long SD) が得られる例もみられた. 小林ら（東 京女子医大, 泌尿器科) は自己活性化 $\gamma \delta$ 型T細 胞を標準療法不応の腎癌に投与した結果を報告し た. $\gamma \delta$ 型T細胞は発生学的には古くから存在す るT細胞で, 増殖速度が速く, 大量培養が可能で ある. 現在, 先進医療として認可されているが, 今後は前立腺癌, 膀胱癌にも応用を進める方針で あることが示された。

\section{5. 免疫賦活剂}

佃教授（横浜市大, 耳鼻科, 頭頸部外科）は, これまで比較的免疫療法が奏効した頭頸部腫瘍に 対する古典的な免疫賦活剤 $(\mathrm{OK}-432$ や漢方薬) を 併用した集学的治療の変遷を紹介された.
また，佃教授は本学術集会終了後の 9 月にご逝 去された.心から哀悼の意を捧げさせて頂きたい.

\section{おわりに}

特別発言として冲永功太教授 (本学会, 理事長) が本シンポジウムの討議内容ばかりでなく，これ までの免疫療法の歴史ならびに今後の展望を見事 にまとめられた．コンパクトでありながら充実し た内容で，司会の不手際から十分な時間がとれな かったことが心残りであった，ぜひ別の機会にま とまった時間での教育講演を拝聴したいと願いつ つ, 本シンポジゥムを閉幕した. 